\title{
Editorial: Border Collisions - Contemporary Flemish Theatre
}

\author{
Lourdes Orozco and Peter M. Boenisch
}

It was one of those fortunate moments in theatre history when, within a short period of time in the 1980s, a whole number of artists who had not worked together nor even met before suddenly emerged from Flanders. These pioneers blended forms, blurred aesthetics and invented then unknown performance formats, and in so doing firmly established the Dutch-speaking part of Belgium on the map of experimental performance practice. Artists such as Anne Teresa De Keersmaeker, Wim Vandekeybus, Jan Fabre, Jan Lauwers, Jan Decorte, Luk Perceval, Michael Laub, Ivo van Hove, Guy Cassiers and Alain Platel were among those to spread the word of a 'Flemish wave' internationally. Three decades on, the next generation continues to defy the discipline's boundaries and expectations, and to challenge even the very stretched and widened notions shaped by their predecessors. In the twenty-first century, Kris Verdonck, Merlin Spie, Eric Joris, Vincent Dunoyer, Lisi Estaras, Union Suspecte, Chokri Ben Chikha, Ontroerend Goed and Ruud Gielens are among those who most prominently expand what already appears to be a legacy.

Yet, in contrast to other tentative periodizations of recent performance history, 'contemporary Flemish theatre' resists being pinned down temporally, aesthetically, and even geographically. There are no clear markers such as 'April 1968', '1970s Greenwich Village', or 'post- modernism'; not even 'postdramatic theatre' is fully successful in offering a common base or a set of shared reference points. Contemporary Flemish theatre is not a coherent artistic 'movement' with a shared aesthetic programme or a common artistic background, and the range of disparate artists all have their individual, often even transnational biographies. Surveying thirty years of radical performance practice from Flanders from an outside perspective (certainly shaped by both our own individual backgrounds and journeys between Catalan, Spanish, Latin American, German and English contexts), as editors we were confronted with a continuous flux rather than with a coherent narrative. Approaching contemporary Flemish theatre meant, we soon realized, an engagement and participation in an ongoing dialogue with contemporary critical-aesthetic debates as well as with the socio-political contexts in which they take place. Even in its most idiosyncratic and blatantly obscure forms, the Flemish is a 'thinking theatre' that is attuned to topical discourses that far transcend the realm of art and performance, and participates and intervenes in them in an embodied and performative way.

Correspondingly, the articles included in this issue engage with contemporary Flemish theatre situated within its cultural and political context, while avoiding attempts at narrating 'the history' of this region's theatre, or imposing any other 'master-logic' that might suggest a chronological, ordered evolution. At different but interconnected levels, the contributions disclose how various forms and practices - from dance and the staging of classics to performance and multimedia work take (a) place within Flanders. They reiterate the productive freedom produced by the very uncertainty governing the national and aesthetic-disciplinary origins of Flemish theatre, and its refusal to clearly 'belong to' only one defined discipline. In this way, 'Border Collisions' offers an insight into Flemish contemporary practices at the crossroads of theatre, performance, politics and history.

The 'Flemish wave' effectively started from a clean sheet with no institutions, no norms, conventions or expectations, no theatre heritage or imposing traditions. Even the ShakespeareMolière-Goethe lineage of classics was more watched from the sidelines than actively shared. 
As choreographer Alain Platel notes in his conversation with Lou Cope, 'there were no fathers to be killed. There was only a wasteland and no money. So everything was possible' (p. 417). Platel (who dedicated his most recent work, Out of Context [2010], to the late Pina Bausch), as well as directors Jan Lauwers and Ivo van Hove, in the interviews contained in this issue, explicitly or implicitly disclose and reflect on backdrops to and influences on their own work as it emerged and took its present shape. These are as diverse as Bausch, the (visual) art history of the Netherlands and Flanders, modernist art, Peter Stein, and the records of the Sex Pistols. It also becomes clear, in the interviews and elsewhere, that these practitioners offer, in their very works, as insightful and challenging a reflection as any critical method from the outside could provide. Given Hans-Thies Lehmann's recognition of the inspirational role that Jan Lauwers' own Needcompany (at the time a regular presence at Frankfurt's Theater am Turm which co-produced many of their early works) played in the development of his influential concept of 'postdramatic theatre', it is not surprising that the postdramatic paradigm is a particularly resonant framework for several contributions throughout this issue.

Rudi Laermans opens with his reflections on thirty years, some generations, and several genrefications of 'new dance' and choreography from Flanders. He discusses what he terms 'choreography in general'. This essentially reflexive approach that initially served to expose, interrogate and challenge some of the all-too-familiar performance conventions, has been extended to cut productively across theatrical means and genres 'in general'. Strategies such as isolation and amplification tie together bodies, texts, sets, human performers and non-human objects alike, as they are presented, choreographed and performed on stage. Importantly, the act of watching a performance is equally integrated into the equation. The spectator is no longer a passive subject. Christel Stalpaert, meanwhile, gains a similar diagnosis from three generations of directors working on the most canonical English playwright. In the Shakespeare productions of Jan Decorte, Jan Lauwers and Peter Verhelst, Stalpaert situates the directors' reluctance towards dramatic action in the tradition of Maurice Maeterlinck's symbolist static drama. Behind the apparent lethargy, indifference and despair that dominate these approaches to the Bard's texts, she perceives the ambivalent potentialities of a contemporary Deleuzian 'aesthetics of intensities'. It is precisely by engaging with canonical Shakespeare that these directors tackle what Stalpaert describes - using Simon During's words - as 'delirium of mimesis' (p. 439) and resist the split between theatre and society in the present. Similar political dimensions of the postdramatic move beyond representation are emphasized in Luk van den Dries and Thomas Crombez's discussion of the works of Jan Fabre and tg STAN, who stand for two generations of performance art emerging from Antwerp.

Yet the authors not only draw on the immediate local context - including the success of extreme right-wing parties at local elections - they also establish further connections with the historic avant-garde and, in particular, with the theatre of Bertolt Brecht and Erwin Piscator. On this basis they come to identify what could be termed, with Jacques Rancière in mind, the 'politicity' in the use of corporeal physicality and rhetoric enunciation in performance. A different, yet no less vital perspective on the political of theatre history and performance traditions emerges from Karel Vanhaesebrouck's article. His analysis explores young theatre artists who employ theatre and performance traditions precisely to confront the darker side of Flemish history, and specifically the crucial, unresolved problem of 'the nation' within the curious virtual state that is Belgium. ${ }^{1}$ By drawing on forms and playwrights that have been connected to nationalism and the dark history of Flemish collaboration with the Nazi regime in the time of the occupation, these artists, quite paradoxically, manage to create what may be described as international Flemish national theatre': a theatre that, within its complex dramaturgic equations, reflects the notions of heritage and legacy not by focusing on the past that has gone, but rather by demonstrating a commitment to the present and the future. These artists revisit some of the emancipatory origins of Flemish nationalism, while not shying away from its troubling aspects, thus negotiating rather than negating the contentious site of 'national identity'. In fact, they show a way of contesting its usurpation and instrumentalization by extreme right-wing politicians and a reactionary 'vox pop'. 
Such challenges to the category of 'the nation' seem particularly pertinent in times when Belgian 'national' politics regularly makes international news headlines. Early in 2010, the country's politicians decided to safeguard its 'European-ness' by banning the burka from public sight. ${ }^{2}$ At the time of writing this introduction, in June 2010, the Belgian government had stumbled once again over the unresolved tensions between the Dutch-speaking Flemish and the Frenchspeaking Wallonian regions, whose fluent boundaries in the vicinity of Brussels, the (officially bilingual) capital, fuel conflicts even further. ${ }^{3}$ A new election saw Flemish separatists lead in parliamentary representation, stirring further uncertainty about the future of the country. At the same time, a growing number of people living in the region, not least in Brussels, do not feel allegiance to either the Flemish or the Wallonian side of the Belgian dispute: immigrants as well as so called allochtone (second- or third-generation) Flemish have become a still largely unacknowledged reality of the 'Flemish nation' today. Yet Flemish theatre may offer a way out of the deadlock, not only because of the international biographies and passports of many of its performers. From the outset, it has been ostensibly international, as co-productions and festivals abroad facilitated and fostered the works of most of its prominent directors and choreographers. At the same time, favourable working conditions and funding structures attracted international artists such as American-born choreographer Meg Stuart and former Wooster Group video artist Chris Kondek in the 1980s and 1990s, and more recently, Heine Avdal and Yukiko Shinozaki of company deepblue, and Palestinian performer Tarek Halaby. They have become an integral part of 'Flemish theatre'.

This somewhat 'impure' stance of Flemish theatre, in a term proposed by Van den Dries and Crombez in their article (p. 421), its 'metissage', as Alain Platel terms it in his conversation with Lou Cope (p. 419), in fact points to a most vital aspect of Flemish theatre as we have encountered it working on this special issue. This theatre is simultaneously local and global, dramatic - textbased - and devised, highbrow intellectual and popular emotional, rigorously aesthetic and politically engaged. It is a paradigm of being 'in between', transcending the regimes of the 'post' phenomena (the post-modern, the post-industrial, the post-colonial, the post-communist, even the post-historic, and most certainly in our context, the post-dramatic) which largely dominated western culture as the first generation of Flemish theatre-makers came to the fore. A decade into the twenty-first century, Flemish theatre demands and equally offers its own different optic: a dynamism that is fuelled by being inter-national, inter-disciplinary, and inter-medial. The prefix 'inter-' points adequately to the contemporary states of global flux, to the continuous transitions that no longer point to any defined goal, let alone to a utopian destination, and to the pivotal present-day experience of either strategically leaving behind, or of being helplessly left behind and bereft of sure and safe grounds. From its beginnings, Flemish theatre has seriously embraced the blurring of borders and remapping of territories that produces the privileged, yet also precarious and volatile position of 'being in-between'. Such interesting intersections, interfaces and inter- plays, often without tangible intentions, are at the core of the diverse forms and formats of contemporary Flemish theatre, and provide a link between the several generations of practitioners in a flexible and non- dogmatic way.

The 'inter-' prefix also appropriately reflects, and performatively articulates, the experience of a changing political and social landscape, especially as felt by the 'Old Europe'. In this wider context, liminal positions - which Performance Studies, following Victor Turner, Richard Schechner and Erika Fischer-Lichte, has put at the heart of contemporary theatre - seem by force even further radicalized. The preoccupation with the transgression of boundaries, and the experimental linking of defined points of departure and arrival, give way to even more ambiguous states. In various forms, the contributions in this issue analyse productions which reflect a shift in metaphorical location: works which find themselves neither here nor there, yet paradoxically also both here and there - thus, paradigmatically, within the 'inter'. 'Why should I restrict myself?' asks Jan Lauwers in his conversation with Jérôme Sans (p. 449), cherishing not only the opportunity to work in theatre as well as in film and visual arts, but also the uncertainty with regards to the labelling of his work, his practices and the ways in which they are disseminated. Is Needcompany's stage 
work theatre, dance, performance art, dance- theatre, visual arts? Should it be 'appropriately' shown in theatres, dance venues, art galleries, or multidisciplinary arts centres?

Similarly, Jan Fabre's work is paradigmatic of the Flemish interdisciplinary practices that not so much ignored as challenged and redefined borders between, and preconceptions about, established genres, aesthetics and methodologies. The arrival of this first generation of Flemish artists happened just as the influence of the post-World War II theatre avantgarde (from Tadeusz Kantor and Merce Cunningham to Pina Bausch, The Living Theatre, Wooster Group and Robert Wilson) was waning. The Flemish theatre-makers did not just reproduce the theatrical innovations of these international artists on local stages. Instead, they established a dialogue with them and brought specific Flemish, and often local or even individual, backgrounds and contexts to this aesthetic discussion. More importantly, while fierce battles continued to be fought elsewhere - especially those between theatre and performance - and Performance Art became a discipline in its own right, Flemish theatre-makers paradigmatically ignored borders rather than reinstating them through labels such as 'devised performance', 'physical theatre' or 'site-specific performance'. Merging, fusing and bringing together elements from distinct art forms, Flemish theatre continues to challenge and escape the branding of marketable 'disciplines'.

Can this interdisciplinary transgression therefore become a model for an emancipatory and engaged reimagination of categories of the (inter-) national amid the global markets and the reign of profitable entertainment? Defending art against 'the vulgar capitalist system' (p. 452), Jan Lauwers insists on the fact that art cannot, and must not, be measured by applause and ticket sales. 'Theatre is pointless and it lacks economic potential, at least in Flanders. So theatre is a form of freedom which to my mind is greatly underestimated' (p. 452). It is here where the national as well as the disciplinary ambiguities and dynamics of Flemish theatre both reflect and simultaneously tackle and interrupt the socio-cultural and aesthetico-political implications of global markets, the diffuse national hegemonies and local power structures that rule contemporary societies, and the current omnipresence of an all-connecting digital mediasphere (above all, the inter-net). By being often radically local and annoyingly idiosyncratic, Flemish theatre offers its most interesting engagement with wider cultural and socio-political issues. The characteristic 'intermediality' of these practices is a decisive factor at work here. Many works actively interrogate easily marketable theatre traditions and the 'products' of the canon. Anne Teresa De Keersmaeker's reworking of classical ballet and modern dance, Ivo van Hove's controversial stagings of American classics (Eugene O'Neill, Tennessee Williams), Jan Lauwers' and others' Shakespeare productions, or the collective rhetorics of $\operatorname{tg}$ STAN (in their productions of Racine, Gorky, Pinter, Bernhard and others) are examples of this. Then, there is the directly and more literally intermedial adaptation of film scripts, as again with van Hove (Pier Paolo Pasolini, John Cassavettes, Ingmar Bergman), the staging of novels and literary texts by Guy Cassiers (Marguerite Duras, Roddy Doyle, Marcel Proust) and tg STAN's textual montages around a theme, where they draw on a variety of material, ranging from plays and short stories to press briefings from the US military and websites of arms manufacturers.

On this basis, recent Flemish works not only continue to redefine disciplinary and institutional territories, but also, as Kurt Vanhoutte argues, they 'register the effects of a postindustrial economy on our senses' (p. 477). By offering ambiguous, contradictory, or sheer overwhelming sensory experiences - as not the least in the works of Kris Verdonck and Eric Joris/CREW Vanhoutte suggests that these works allow the spectators spaces to explore and develop their facilities in cognitive mapping in order to find "a new sense of "being there" in a world determined by technology' (p. 478). Similarly, director Ivo van Hove, whose productions have often been described as a 'theatre of experience', states - in conversation with Johan Thielemans - how the growing mediatization of society has made, for him, the arrival of the 'real' to the stage a necessity; a shift that has effectively counteracted the total virtualization of almost all cultural practices (pp. 457-59). Van Hove himself has, for example, used cows, snakes, onstage cooking, live feeds and spatial arrangements that irritate the spectators' perception in order to trigger such 'reality effects'. He invites, provokes and even demands a new spectatorial 
'cognitive mapping' that transcends the consumption of linear stories and psychological characters, while still relying on the framework of 'drama'. Disrupting linear narratives and bringing in the real, van Hove's works successfully disrupt the make- believe world so carefully established by nineteenth-century theatre practices, and yet display a commitment to classical texts. Again, this ambiguity of a 'both-and' is decisive. There is always the danger of creating high-tech spectacles, or of using the audience's 'special experience' as a mere marketing ploy. Theatre, however, must not become yet another commodity within the global 'entertainment industry', a commercial 'event' designed to provide another spectacular 'kick', as Wouter Hillaert warns in his provocative and passionate call for a theatre liberated from the claws of 'exchange value'. Theatre, in Hillaert's view, stands on a dangerous ridge, with market forces hovering, ready to rapidly assimilate the 'new', the 'radical', the 'different' into its marketing structures.

Flemish theatre - always on the verge of becoming a well-selling 'brand' itself - is not aloof to these dangers, and maintaining artistic integrity is one of the struggles experienced certainly not exclusively by its practitioners. With a strong presence on the international festival circuit and regular appearances on stages across the world, Flemish directors, choreographers, designers, dancers and performers have become difficult to ignore when it comes to writing an account of contemporary theatre and performance practices. Dynamic interplays between physical, spatial and rhythmic textures; the reworking of texts; a peculiar production of meaning and feeling; a commitment to the presentation of mediated and live events; and the facilitation of dialogues between past and present - these have allowed contemporary Flemish theatre to blow open the protective shields of tradition, form and ideology in a unique way. More importantly, this 'marginal theatre' from Flanders - as it was referred to by its makers in the early days of its existence - is a stateless theatre that has challenged established traditions of representation, genres and audience perception without ever attempting to present a 'new solution' in the old gesture of the avantgarde. This theatre continues to reinvent its non-locatable 'in-between- ness' which also, in a potentially productive and yet challenging way, obscures its own identity and resists security and stability.

This persistence in remaining aesthetically and geographically un- locatable raises many poignant questions and debates that are vital for theatre and performance at large within the early twentyfirst century's digitized global culture. Flemish practitioners have fully embraced these questions, starting by using the terms 'theatre' and 'performance' interchangeably. Their willingness to challenge the labelling of their works has also led them to refer to the most outlandish dramaturgic structures without characters and/or written text as 'a play'. This challenging of dramaturgical laws has not stopped directors from collaborating with the region's conventional playwrights. The most notable examples of this practice are Arne Sierens and Pol Hayvaert. The artistic challenges raised by these works and their strategic 'impurity', as well as their impact on fellow artists, audiences and academics worldwide, remain barely addressed within an international (notably anglophone) context. While some links have been established with English-speaking nations such as Ireland and Scotland through the Dublin, Belfast and Edinburgh theatre festivals and the Tramway Theatre in Glasgow, Flemish theatre remains for many irritatingly foreign, specifically within the commercially and policy-driven 'theatre industries' of the United States and England. Too often, critics cannot help but discredit the work as 'Eurotrash', finding nothing but 'wilful obscurity, overthe-top stagecraft, auteur-ish egocentrism' (p. 464), as David Willinger reports in his review of some Flemish theatre excursions to New York City. Yet these disparaging responses testify to the helplessness and lack of conceptual categories demonstrated by critics and audiences when faced by performances that blur, mix and obscure borders, frontiers and territories, while forcefully refusing their marketable reification. This special issue of Contemporary Theatre Review is an attempt to stimulate some understanding, to prompt a debate, and to open up to an international readership the discourses that have shaped contemporary Flemish theatre over the past thirty years. However necessarily selective it might be, the issue presents a series of stimulating 'tasters' that might highlight some of the central issues emerging from these practices and practitioners. We hope this issue plays some role in encouraging a movement towards the 
much-needed inclusion of Flemish theatre within international (not least Anglophone) theatre scholarship and theoretical reflection, while inciting the readers' curiosity into further theatrical journeys to this vibrant and creative region. ${ }^{4}$

1. See Jon Henley, 'Bye, Bye Belgium', The Guardian, 13 November 2007, http://www.guardian.co.uk/g2/story/0,,2209988,00.html [accessed 4 May 2010].

2. See BBC News Online, 'Belgian Lawmakers Pass Burka Ban', 30 April 2010, http:// news.bbc.co.uk/1/hi/ world/europe/8652861.stm [accessed 4 May 2010].

3. See BBC News Online, 'Belgium's King Accepts Yves Leterme's Resignation', 26 April 2010, http://news.bbc.co.uk/1/hi/ world/europe/8645344.stm [accessed 4 May 2010].

4. We would like to thank all contributors to this special issue and the many readers who provided detailed comments on early drafts and versions Maria Delgado and David Bradby have offered, as ever, generous support, help and advice, and for that they deserve our special thanks. The work on this special issue was also supported by the European Theatre Research Network (ETRN) at the University of Kent. We also thank the photographers who allowed us to use their work and the companies who facilitated our research. Special thanks go to Elke Janssens from Needcompany, Mark Geurden from Troubleyn/Jan Fabre, Wouter van Ransbeck and Wietske van Solingen of Toneelgroep Amsterdam, the Vlaams Theatre Institute, and Johan Callens at Vrije Universiteit Brussels, and to Elyssa Livergant, CTR editorial assistant, as well as to our patient production editor, Victoria Rose at Taylor and Francis. 